\title{
Intra-African Trade and Spatial Dependence: Revisiting Africa Intra-Trade Determinants with a Spatial Structural Gravity Model
}

\author{
Mariame Bakouan1, Idrissa Mohammed Ouedraogo² \\ ${ }^{1}$ Economics Department, Université Norbert Zongo, Koudougou, Burkina Faso \\ ${ }^{2}$ Economics Department, Université Aube Nouvelle, Ouagadougou, Burkina Faso \\ Email: mariamebakouan@gmail.com, idriss_mo@yahoo.fr
}

How to cite this paper: Bakouan, M., \& Ouedraogo, I. M. (2022). Intra-African Trade and Spatial Dependence: Revisiting Africa Intra-Trade Determinants with a Spatial Structural Gravity Model. Theoretical Economics Letters, 12, 149-171.

https://doi.org/10.4236/tel.2022.121009

Received: December 17, 2021

Accepted: February 5, 2022

Published: February 8, 2022

Copyright $\odot 2022$ by author(s) and Scientific Research Publishing Inc. This work is licensed under the Creative Commons Attribution International License (CC BY 4.0).

http://creativecommons.org/licenses/by/4.0/

\begin{abstract}
The objective of our paper is to revisit African intra-trade determinants once taking into account potential spatial spillover effect due to the third country dependence. Recently, several studies have shown the importance of taking into account the spatial effect. We examined total exports flows, industrial trade flows and agricultural trade flows of 40 countries in 2002-2018 and we detected a positive spatial autocorrelation and the Spatial Autoregressive gravity model is identified as an appropriate way to model the spatial dependence. The results show that distance doesn't affect agricultural products trade, institutional factors of destination country and neighboring countries affect intra-African trade. Except SADC area, intra-African trade is largely dominated by agricultural products. To reduce poverty through trade intensification, the regional integration process in Africa must grant an important place to industrialization policies, conflict resolution and strengthening cooperation.
\end{abstract}

\section{Keywords}

Intra-Trade, Regional Integration, Spatial Structural Gravity Model

\section{Introduction}

Since Independence in 1960, strengthening relationship between African countries in order to reduce poverty is presented as the only solution for the continent. The objective of Africa integration process is to induce the development through trade increasing. Despite all the efforts, the trade flows between African economies still remain low compared to the other regions in the world. For example, in 2015, the Africa-intra exports were estimated at $19 \%$ against $51 \%$ for 
Asia, 68\% for Europe, 50\% for North America, and 24\% for South and Central America ${ }^{1}$. In the literature, many factors are identified to justify the low level of trade between African countries, but the market narrowness is identified as a major determinant. In fact, the African market is the most segmented in the world, with higher trade costs compared to the other regions ${ }^{2}$. Hence, trade costs between African economies tend to be higher than trade costs of Africa with the rest of the world ${ }^{3}$. In view of this, the summit of heads of State and Government of the African Union in 2012, on the theme "Africa intra-trade intensification", decided to accelerate the continental free trade area creation. Thus, the African Union laid, on March 21, 2018, the bases of the continental free trade area (ZLEC) in Kigali in Rwanda ${ }^{4}$. Since May 2020, the continental free area is created and represented the largest free-trade area in the world and it is expected to increase trade by $60 \%$. In fact, regional integration is presented as an opportunity to broaden the market's size, also as an alternative to the negative effects of asymmetrical multilateralism. By increasing the market size, the regional integration offers additional opportunities to attract foreign direct investment, achieve the critical mass necessary for a competitive supply capacity. It also induces the capacity to absorb external shocks which otherwise would have had a more pronounced impact on each economy taken individually.

Indeed, the economic activities localization is dictated by three main variables: the market size, the production cost and the availability of relevant factors of production; and market access (Krugman, 1991).

Classical and neoclassical theories of trade and the theories of customs unions Viner (1950) attest that integration is a vector for trade promotion, as it leads to further specialization of countries based on their comparative advantages. In fact, each country will export the good that uses its abundant factor intensively. New theories of trade based on market assumptions and economies of scale show that the increase in market size induced by integration makes it possible to exploit economies of scale due to the fall in the average costs of production of firms present on the market and a diversification of production that improves consumer satisfaction. Studies focused on African countries also support the assumption that regional integration stimulates trade (Masson \& Pattillo, 2004; Tsangarides \& Qureshi, 2008; Kamau, 2010; Tapsoba, 2011; Von Uexkull, 2012). Kamau (2010) believes that trading blocs such as COMESA, EAC and SADC promote growth, and Von Uexkull (2012) shows that intra-ECOWAS exports contribute to increasing productivity, diversification and job creation. Therefore,

${ }^{1}$ World Trade Organization Trade Statistic 2016.

${ }^{2}$ CUNCED (2009): "Le développement économique en Afrique Rapport 2009: Renforcerl'intégration économique régionale pour le développement de l'Afrique". Nations Unies, NewYork et Genève, 2009; CEA (2010).

${ }^{3}$ UNDP Report 2011: Regional Integration and Human Development: A Path for Africa.

${ }^{4}$ At the African Union summit in Kigali in March 2018, the agreement establishing the African treaty was signed by 54 of the $55 \mathrm{AU}$ member states and ratified in early 2021 by 34 . The AfCFTA entered into force in May 2020, one month after the 22 necessary states deposited their instruments of ratification with the Chairperson of the AU Commission (thus meeting the minimum requirement required for the entry into force of the agreement). 
through the trade channel, regional integration supports growth. Hence, increasing African trade can play an important role in the countries' development process. Despite efforts to increase trade between African countries, the intra-African trade volume still remains low compared to other regions in the world. Which factors affect trade volume between African economies? Specifically, what is the impact of geographic factors on the level of intra-African trade? Our objective is to revisit the determinants of intra-African trade once taking into account potential spatial dependence due to the third country effect. Many trade-related works use the gravity model with traditional variables such as GDP, proxy of the country's income level and geographical, cultural and institutional variables. The shortcomings of this work are that the trading partners are considered to be isolated, without any interaction with other partners at the same time. The third country effect is set aside. Actually, recent gravity model developed by Anderson and Van Wincoop (2003) integrates spatial interdependence through the multilateral resistance terms. The theoretical model shows that when the multilateral resistances are not controlled it induces an endogeneity bias. We assume that trade between African countries presents spatial effects, and to analyze trade determinants, these effects need to be well specified. By further taking into account multilateral resistance terms, the aim is to identify the factors that affect trade between African countries, by paying attention to spatial effects. Our study is the first which integrate spatial effects in gravity model to analyze African trade determinants.

The rest of this paper is organized as follows: Section 2 presents some stylized facts; Section 3 dwells on the literature review; Section 4 provides the methodology adopted; Section 5 presents the empirical analysis; Section 6 is devoted to the conclusion and the recommendations of the study.

\section{Africa Intra-Trade: Some Stylized Facts}

This section presents the African trade evolution and regional economics communities trade performance.

\subsection{Intra Trade Evolution}

In this section, we present some stylized facts on Africa intra-trade on the period 1997-2018.

The trade evolution (Graph 1) shows that the Africa intra-trade still remains marginal compared to its trade with rest of world. This is the opposite in the European Union where the trade level between members is higher than its trade level with the rest of the world. The graph shows us that African countries trade more with the rest of the world than with each other. Over the period 1996-2018, the average extra-community trade was estimated to 308 million US DOLLARS against an average intra-community trade level of 64.9 million US DOLLARS. Hence, the intra-community trade represented, on average, only $16 \%$ of the Africa total trade. Africa economies are very extrovert because they trade more 


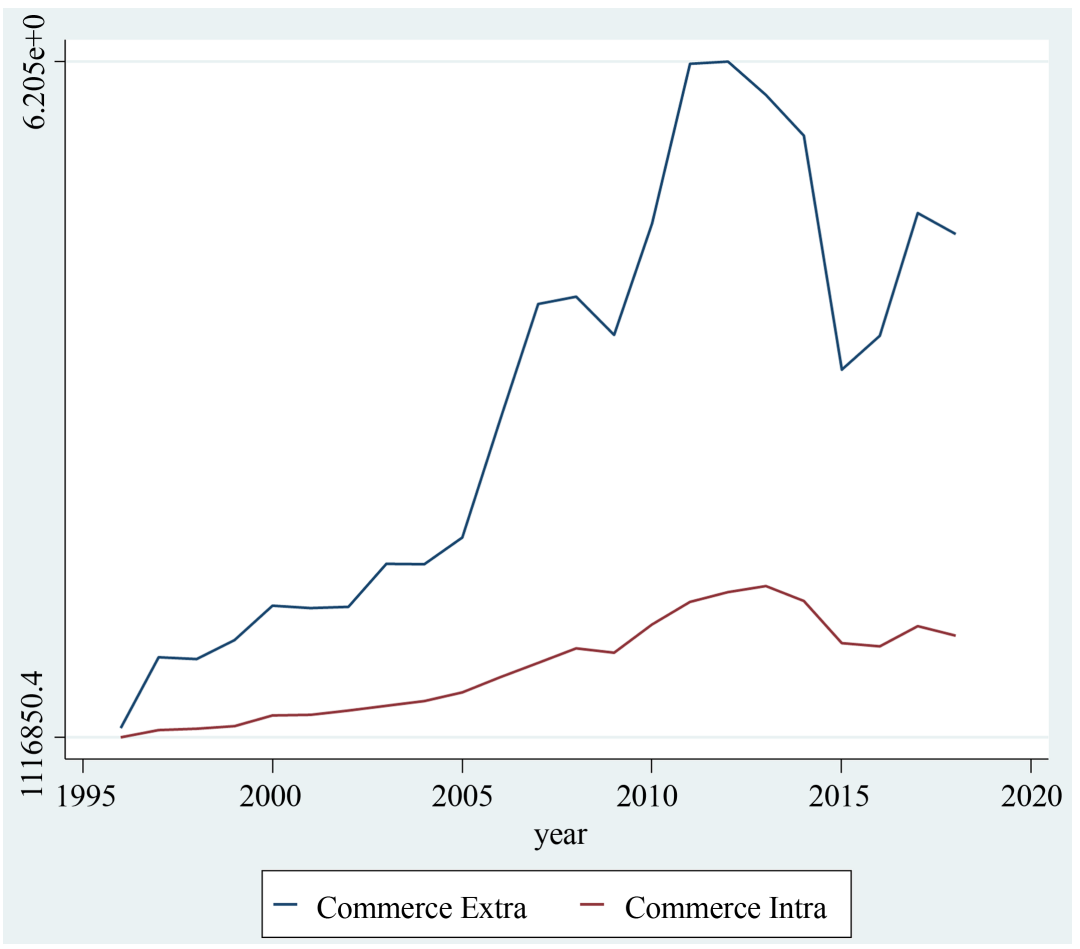

Graph 1. Sub-Saharan Africa trade evolution (1997-2018).

the rest of the world. In this context, does the region integration can promote intra-trade? If the situation is linked to the products export by countries, reduces all the trade barriers can't induce trade increasing.

The integration process in Africa is based on regional economic communities which charged to achieve markets integration. These different communities' objective is trade obstacles reduction in order to promote trade between members. It is, therefore, crucial to analyze the evolution of trade within these different communities.

\subsection{Africa Regional Communities Trade Performance}

Graph 2 and Graph 3 present the regional economic community intra-trade and its trade with other communities (extra-trade) during 1996-2018. Le Graph 2 shows that SADC is the more efficient community considering the trade volume during the period. On the period 1996-2018, the trade between SADC members represents 37.1 million US DOLLARS follows by ECOWAS with 10.1 million US DOLLARS. The graph, also shows that the Central African Community members trade less compared to other communities. The low cooperation between central Africa members can be explained by many crises and leadership problems in this area. In order to assess the cooperation level between the different communities, we also appreciate the intercommunity trade level (Graph 3). The graph shows that SADC and COMESA have more relationship considering the trade volume of the two blocs. During the period, the trade volume from SADC to COMESA members destination is estimated to 11.2 million US 


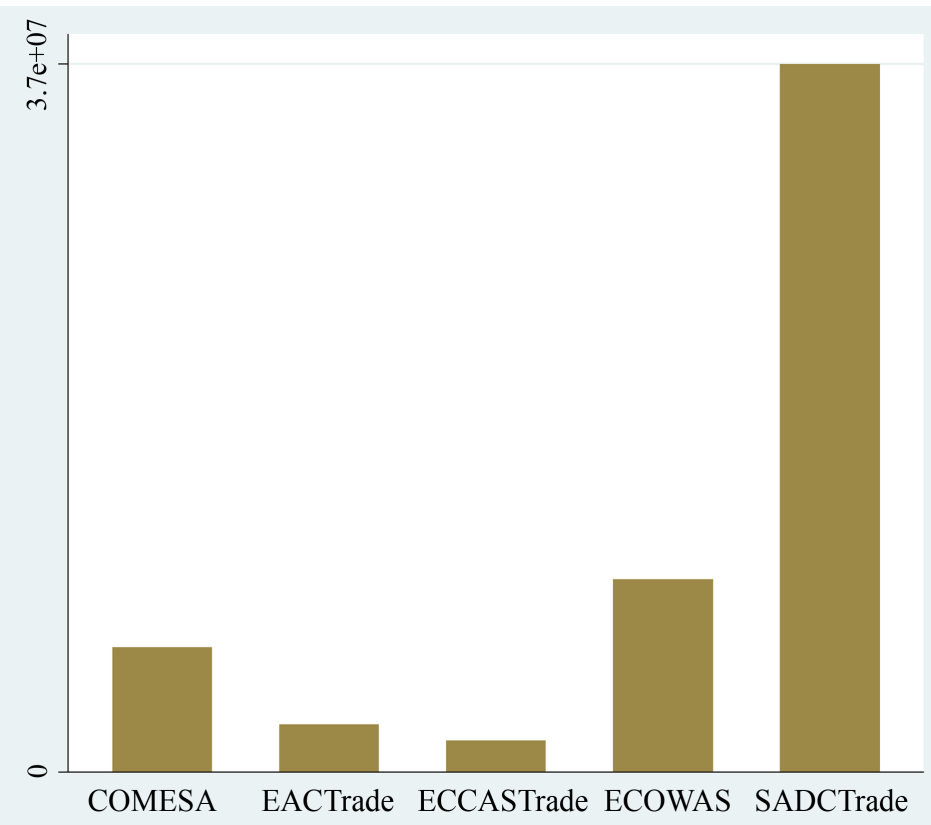

Graph 2. Mean trade of RECs (1997-2018).
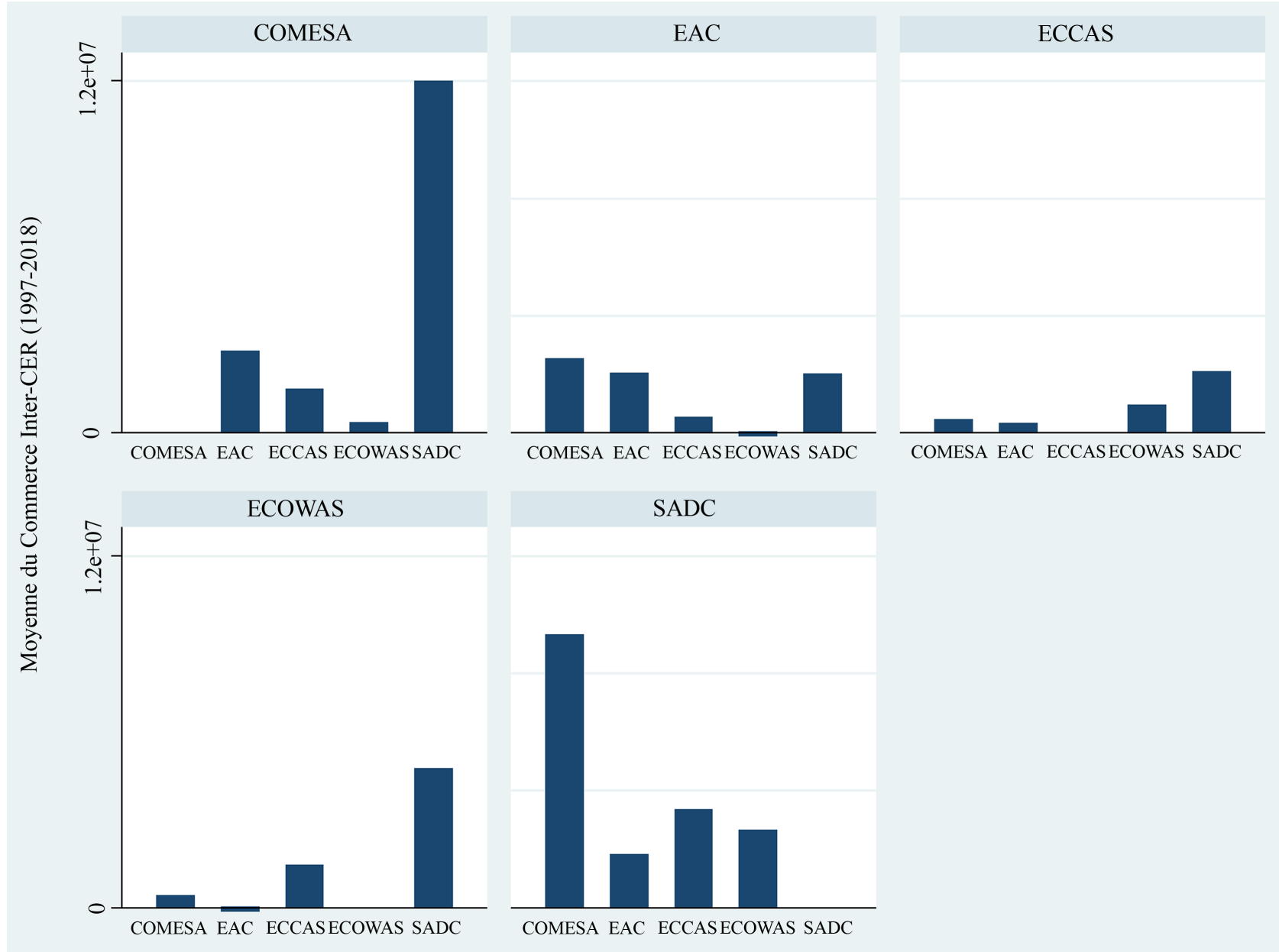

Graph 3. Mean inter-RECs trade (1997-2018). 
DOLLARS, followed by the East-African economies destination with 2.19 million US DOLLARS. At the same moment, COMESA trade to SADC destination is estimated to 11.7 million US DOLLARS, followed by the East Africa economies with 2.8 million US DOLLARS, and Central Africa with 1.5 million US DOLLARS. Our analysis shows that proximity remains an essential factor in economic cooperation's strengthening (Graphs 1-3).

\section{Literature Review}

This literature review provides an overview of the works dealing with the issues on trade determinants. The section is decomposed into two subsections. The first focuses on the works investigating trade determinants. The second provides an overview emphasizing the importance of spatial effects in trade literature.

\subsection{Review of Empirical Issues}

In the literature it has been shown that the gravity model is appropriate for the empirical analysis of the determinants of international trade. The gravity model identifies the size of a country is the major driver of trade activities. The model shows that trade costs are composed by geographic factors, cultural proximity, regional trade agreements and institutional factors. Geographic factors are bilateral distance, common border, landlockedness. Bilateral distance and landlockedness negatively affect the trade level while the common border positively affects trade volume. Indeed, landlockedness contributes to isolate the country and enhance the negative effect of the distance on trade volume. For example, Coulibaly \& Fontagné (2006) shows that landlocked developing countries trade $40 \%$ less compared to $30 \%$ for landlocked developed countries. In developing countries, geography remains a crucial determinant of trade and economic growth. Gallup et al. (1999) note that the geographic factor and the climate largely influence the income levels and economic growth of countries through transport costs, various diseases and agricultural productivity. Cultural proximity is another factor which positively affects bilateral trade. Hence, common colonial ties, common language are trade promotion factors. Trade agreements by reducing trade barriers can increase trade between members but often at a cost to trade with other trading partners (Barbalet et al., 2015; Ngepah \& Udeagha, 2018; Bi \& Kong, 2022). Kaminchia (2019) reveals that the cost of trade among East African Community (EAC) countries is higher than domestic trading, but the cost of trading between EAC members and non-EAC countries is much higher than trade between EAC members.

The literature points out that better institutional quality might increase economic activities in Africa, and trade in particular (Asongu et al., 2018; Canh et al., 2021). Canh et al. (2021) found that Internet, and mobile phone use have greater impacts on trade openness in African countries that have a better institutional framework.

One of main shortcomings flaw the estimation of gravity model in previous 
studies is they fail to account for the multilateral resistance term (MRT). This omission makes the estimates from standard gravity model bias and inconsistent. These studies consider that countries are independent and omit the third country effect.

\subsection{Trade Flows and Spatial Effects}

The first law of geography developed by Tobler (1979) says that everything is related to everything else. However, things nearer are more closely related than things farther away. Indeed, economy and geography theories highlight spatial externalities called spillover effects. Trade activities improvements in a country can lead improvements in trade activities of their neighboring countries through spillover effects. In Africa economies context, a political instability in a country affects his spatial neighbors and reduces his trade with some trade partner which depends of this country infrastructure. These countries remained highly dependent of the quality of infrastructure, stability, and the various obstacles encountered in neighboring countries with access to the sea. Different authors show, at theoretical and empirical level, the necessity to integrate the effect of structural changes in an economy on their spatial neighbors (Baltagi et al., 2007; Baltagi, 2008; Hall et Petroulas, 2008). In international economic, the spatial dependence is due to the role of the third country. Hence, economies are related to each other, and specifications must integrate it. The third country determines the spatial spillover, which can be positive or negative effect. In fact, the trade between the couple $i$ and $j$ depends on the relative cost: which corresponds to the cost from $i$ to $j$ compared with the cost from $i$ to $k$, where $k$ is the neighbor of $j$ (Adam \& Cobham, 2007). Hence, different studies underscore the necessity to integrate the effect of the spatial dependence in the gravity model (Kelejian, Tavlas, \& Petroulas, 2011; Metulini, 2013).

Traditional gravity model takes geography into account through the variables like distance, common border, common language, colonial links or common currency. The distance variable introduced in the gravity model plays a "black box" role (Prager \& Thisse, 2010). Nevertheless, these variables may be inadequate because a shock which affects a country can have an effect on their neighbors. In addition, the integration process based on trade barriers removal and transport costs reduction induce markets integration and increase economies interdependence. Likewise, the use of data located in space leads both to the spatial autocorrelation (Porojan, 2001; Baumont et al., 2000) linked to the interdependence of geographical observations and the spatial heterogeneity explained by the spatial differentiation of variables (Le Gallo, 2000).

\section{Econometric Estimation}

Since Tinbergen (1962), the gravity model is the most used empirical model in international economics for its excellent empirical robustness in describing trade flows. The gravity model allows to analyze the main determinants of trade 
flows, the presence of geographical effects, on one hand, and political, on the other, that limit the flows, and the existence of positive effects attributed to the Free-Trade Agreement.

\subsection{Gravity Model Formulation}

Under the assumptions of identical constant elasticity of substitution (CES) preferences across $\mathrm{n}$ countries for national varieties differentiated by place of origin Armington (1969); Anderson, (1979) derived the gravity model first theoretical foundations. From these analyzes, Anderson and Van Wincoop (2003) derive the structural gravity model defined as follows:

$$
\begin{aligned}
& X_{i j}=\frac{Y_{i} E_{j}}{Y}\left(\frac{t_{i j}}{\Pi_{i} P_{j}}\right)^{(1-\sigma)} \\
& \Pi_{i}^{1-\sigma}=\sum_{j}\left(\frac{t_{i j}}{P_{j}}\right)^{1-\sigma} \frac{E_{j}}{Y} \\
& P_{j}^{1-\sigma}=\sum_{i}\left(\frac{t_{i j}}{P_{j}}\right)^{1-\sigma} \frac{Y_{i}}{Y}
\end{aligned}
$$

where, $X_{i j}$ denotes the value of shipments at destination prices from region of origin $i$ to region of destination $j . E_{j}$ is the expenditure at destination $j$ from all origins and $Y_{i}$ denotes the sales at destination prices from $i$ to all destinations. $t_{i j} \geq 1$ denotes the variable trade cost factor on shipments of goods or services from $i$ to $j, \sigma$ is the elasticity of substitution across varieties. $\Pi_{i}$, Equation (2), is the outward multilateral resistance (OMR), which aggregates $i$ s outward trade costs relative to destination price indexes. $P_{j}$, Equation (3), is the inward multilateral resistance (IMR), which aggregates the incidence of trade costs on consumers in each country, and also the CES price index of the demand system. Hence, in the gravity model derived by Anderson \& Van Wincoop (2003) the multilateral resistance terms are unknown. By log-linearizing the Equation (1), we obtain:

$$
\ln \left(\frac{X_{i j}}{Y_{i} E_{j}}\right)=\ln G+\Upsilon_{i}+\Upsilon_{j}-(\sigma-1) \ln t_{i j}
$$

Here, $\ln \left(\frac{X_{i j}}{Y_{i} E_{j}}\right)$ adjusted exports flows; $\ln G=-\ln Y, \Upsilon_{i}=(\sigma-1) \ln \Pi_{i}$ exporter fixed effects and $\Upsilon_{j}=(\sigma-1) \ln P_{j}$ importer fixed effects. In the literature, country fixed effects are used as proxies of the multilateral resistance terms (Feenstra, 2004; Redding \& Venables, 2004; Head \& Mayer, 2014; Fally, 2015). Trade costs $t_{i j}$ are composed by geographic, cultural and institutional factors. The geographic factors are mainly made up of the bilateral distance dist ${ }_{i j}$, landlocked $\operatorname{Landck}_{(i) j}$, common border ComBor ${ }_{i j}$. The existence of cultural links as the sharing of the same language ComLang ${ }_{i j}$, colonial links Comcol $_{i j}$ are trade 
promotion factors. Institutional factors impact the level of country's development (Acemoglu et al., 2001). The literature shows that these factors also affect the level of bilateral trade (De Groot et al., 2003; Levchenko, 2007; Nordås, 2018; Alhassan \& Payaslioglu, 2019). In the same dynamic, it is assumed that political and economic institutions affect the level of trade through trade costs. Thus, the determinants of trade costs are augmented by institutional variables. Colonial links are also perceived as a proxy of institutional factors because countries with the same colonial history have always got the same legal system. Trade agreements $A C R_{i j}$, through the reduction of tariff barriers, reduce trade costs. The error term $\varepsilon_{i j}$ makes it possible to take into account all relevant explanatory variables not available. Thus, the model (4) is rewritten in panel as follows:

$$
\begin{aligned}
y_{i j, t}= & \Upsilon_{i, t}+\Upsilon_{j, t}+\beta_{1} \ln \operatorname{dist}_{i j}+\beta_{2} \operatorname{Landck}_{(i) j}+\beta_{3} \operatorname{ComBor}_{i j} \\
& +\beta_{4} \operatorname{ComLang}_{i j}+\beta_{5} \operatorname{ComCol}_{i j}+\beta_{6} \operatorname{InstQu}_{(i) j, t}+\beta_{7} \text { ACR }_{i j}+\varepsilon_{i j, t}
\end{aligned}
$$

With $y_{i j, t}=\ln \left(\frac{X_{i j, t}}{Y_{i, t} E_{j, t}}\right) ; \quad \operatorname{InstQu}_{(i) j, t}$ captures institutions quality indicators in exporting or importing countries. The following signs are expected:

$\beta_{1}=-(\sigma-1) \prec 0 ; \quad \beta_{2}=-(\sigma-1) \prec 0 ; \quad \beta_{3}=-(\sigma-1) \succ 0 ; \quad \beta_{4}=-(\sigma-1) \succ 0 ;$ $\beta_{5}=-(\sigma-1) \succ 0 ; \beta_{6}=-(\sigma-1) \succ 0 ; \quad \beta_{7}=-(\sigma-1) \succ 0$.

Equation (5) shows that bilateral trade is explained as well by variables of the exporting country as by that of the importing country. We rewrite Equation (5) according to the variables of the exporting country and the importing country and the pair:

$$
Y_{O D}=\Upsilon_{O}+\Upsilon_{D}+X_{O} \beta_{O}+X_{D} \beta_{D}+F_{O D} \varsigma_{O D}+\xi
$$

With $Y_{O D}=y_{i j, t}$ adjusted bilateral flows matrix of dimension $n^{2} * t ; X_{O}$ and $X_{D}$ respectively the explanatory variables of the country of origin and the country of destination, matrices of order $n^{2} * t$ by $k$ and $\beta_{O}$ and $\beta_{D}$ vectors of dimension $k$ by 1 of coefficients of the explanatory variables. The parameter $\varsigma_{O D}$ is the vector containing the set of coefficients relating to the matrix $F_{O D}$ of $h$ interaction variables between the origin and the destination, of dimension $n^{2} * t$ by $h$. The error term $\xi$ of dimension $n^{2} * t$ is the vector of residuals, stochastic, independent and identically distributed with zero mean and common variance $\sigma^{2} . \Upsilon_{O}, \Upsilon_{D}$ are respectively the vector of order $n$ that represent the origin and destination fixed effects and $\Upsilon_{t}$ is the T dimension time counterpart. Anderson and Van Wincoop (2003) model provides a theoretical basis for modeling spatial interdependence in international trade; however, space issues are generally not adequately addressed. Indeed, the model implicitly assumes that spatial interdependence arises only from transaction costs. However, with a utility function of CES type where the varieties are raw substitutes, there can be a spatial interdependence between the flows trade, reflecting a spatial autocorrelation between trade flows. Curry (1972) was the first to note the insufficient consideration of spatial dependence in gravity models. Following this, various works 
will also focus on highlighting the presence of spatial autocorrelation in the error terms of classical gravity models (Porojan, 2001; Lee \& Pace, 2005). The autocorrelation presence requires an appropriate estimation method.

\subsection{Gravity Model and Spatial Dependance}

When the Equation (6) is estimated by Ordinary Least Squared (OLS), it is assumed by default that the residual or error term $\xi$ is uncorrelated. However, as mentioned above this is unlikely, there may be spatial autocorrelation between origins and destinations so that $E(\xi) \neq 0$. The spatial economic literature proposed two main ways to model spatial autocorrelation (Anselin, 1988b). The spatial dependence, viewed as a long-run equilibrium of an underlying spatiotemporal process, must be modeled by spatial autoregressive model (SAR). Indeed, the spatial dependence as based on a time-lag relationship describes a diffusion process over space. Hence, the SAR models contain spatial lags of the dependent variable. When spatial dependence derived from omitted variables that exhibit spatial dependence led to a model with spatial lags of both the explanatory and the dependent variable. When spatial dependence derives from omitted variables, the appropriate model is the spatial error model (SEM). The spatial dependence is integrated into analysis though the weights matrix which defines the structure of the spatial components. The spatial matrix called $W$, in cross-sectional model, is an $\mathrm{n}$ by $\mathrm{n}$ dimension, non-negative and sparse. For the elements of this matrix hold that $w_{i j} \succ 0$, and, by convention, $w_{i j}=0$, to prevent an observation from being defined as a neighbor to itself. The spatial model specifications can be adapted for the analysis of international trade with the use of the gravity model. SAR and SEM models derived from the gravity Equation (6) are:

$$
\begin{aligned}
Y_{O D}= & I_{n} \otimes I_{t} \otimes \Upsilon_{O}+I_{n} \otimes I_{t} \otimes \Upsilon_{D}+\rho\left(W_{O D} \otimes I_{t}\right) Y_{O D} \\
& +X_{O} \beta_{O}+X_{D} \beta_{D}+F_{O D} \varsigma_{O D}+\xi
\end{aligned}
$$

And

$$
\begin{aligned}
Y_{O D}= & I_{n} \otimes I_{t} \otimes \Upsilon_{O}+I_{n} \otimes I_{t} \otimes \Upsilon_{D}+X_{O} \beta_{O}+X_{D} \beta_{D} \\
& +F_{O D} \varsigma_{O D}+\lambda\left(W_{O D} \otimes I_{t}\right) \xi+\mu
\end{aligned}
$$

where $I_{n}$ is a vector of ones of dimension $n, I_{t}$ is a vector of ones of dimension $t$. In the model (7), the parameter $\rho$ is the spatial dependence coefficient which captured the spatially lagged dependent variable and describes the intensity of the spatial interaction. $W_{O D}$ is a $n^{2} * n^{2}$ matrix defines as the Kronecker product of $W_{O D}$ with itself, which takes account the interaction between origin and destination neighbors and $\rho\left(W_{O D} \otimes I_{t}\right) Y_{O D}$ representing the spatially weighted mean of neighboring trade value. The SAR model allows, in reduced form, for full interactive heterogeneity of the impact of coefficients or elasticities by means of the so-called global spatial multiplier effect in addition to the global spatial diffusion property of a random shock (Anselin, 2003). In the model (8), the parameter $\lambda$ reflects the intensity of the interdependence between the residues of 
the regression; and, $\mu$ is the error term. This model is characterized, in reduced form, by a global spatial diffusion of a random shock. The spatial parameters $\rho$ and $\lambda$ allow for assessment of the impact of interactions on African countries trade flows. Finally, it is also possible to consider a model with both types of spatial autocorrelation:

$$
\begin{aligned}
Y_{O D}= & I_{n} \otimes I_{t} \otimes \Upsilon_{O}+I_{n} \otimes I_{t} \otimes \Upsilon_{D}+\rho\left(W_{O D} \otimes I_{t}\right) Y_{O D}+X_{O} \beta_{O} \\
& +X_{D} \beta_{D}+F_{O D} S_{O D}+\lambda\left(W_{O D} \otimes I_{t}\right) \xi+\mu
\end{aligned}
$$

When the spatial autocorrelation is present in the sample considered, OLS estimators are biased and not convergent (Le Gallo, 2002). Identify the most appropriates spatial specification and estimation method are a crucial point. In the literature, the appropriate estimation method to end up with correct coefficients is maximum likelihood method (Anselin, 1988a). Following Metulini (2013); Leibrecht and Riedl (2014), we use the inverse distance matrix denoted $W_{\text {dist }}$ to model the spatial interactions. The inverse distance matrix choice is motivated by its ability to connect all the spatial units, unlike the contiguity matrix.

\subsection{Data Description}

In the model, we use three endogenous variables: total exports, industrial exports and agricultural exports. The first variable: total exports allow to identify all the factors which explain the trade level between Africa countries when consider spatial effects. In order to appreciate if factors which explain the intra-Africa trade level are different considering trade flows, we also use industrial and agricultural trade as endogenous variable. This analysis helps to reconsider trade determinants and their impacts when the gravity model is well specified by taking account the spatial effects. Data of total exports, industrial exports and agricultural exports are from COMTRADE and provided by World Integrated Services (WITS) and covers the period 2002-2018 for 40 African countries. Table 1 shows that the mean of total exports on the period is 28,474 thousand of US DOLLARS, with the maximum level estimated at 3.875 million of US DOLLARS. When consider industrial and agricultural, the industrial trade is important than agricultural trade flow. Indeed, in Africa context, the important agricultural trade flow is not followed the formal system. We use the real gross domestic product (GDP) collected from the World Development Indicator (WDI) database as proxy of country revenue and to adjust trade flow. Institutional quality data are provided by the World Bank's Worldwide Governance Indicators (WGI). These indicators obtained from the composite index are ranged between -2.5 to 2.5 , where high values depict a better quality of institutions. Table 1 shows that Africa economies present a quality of institution during the period consider. For example, the mean of corruption control is -0.592 and political stability mean is -0.569 . The gravity traditional variables like bilateral distance, common border, common language, colonial ties and landlocked are provided 
Table 1. Summary statistics.

\begin{tabular}{|c|c|c|c|c|c|}
\hline VARIABLES & Number & Mean & $\begin{array}{l}\text { Standard } \\
\text { Deviation }\end{array}$ & Minimum & Maximum \\
\hline $\begin{array}{c}\text { Exports } \\
\text { (Thousand US } \\
\text { DOLLARS) }\end{array}$ & 5.78 & 28.474 & 183.713 & 0 & $3.875 \mathrm{e}+06$ \\
\hline $\begin{array}{l}\text { Agriculture trade } \\
\text { (Thousand US } \\
\text { DOLLARS) }\end{array}$ & 5.78 & 4.783 & 33.984 & 0 & 903.41 \\
\hline $\begin{array}{l}\text { Industrial trade } \\
\text { (Thousand US } \\
\text { DOLLARS) }\end{array}$ & 5.78 & 23.554 & 159.733 & 0 & $3.152 \mathrm{e}+06$ \\
\hline Political stability & 5.78 & -0.484 & 0.841 & -2.524 & 1.219 \\
\hline Rules of Law & 5.78 & -0.569 & 0.520 & -2.141 & 0.660 \\
\hline Control of Corruption & 5.78 & -0.592 & 0.590 & -1.552 & 1.039 \\
\hline $\begin{array}{l}\text { Real GDP (Millions of } \\
\text { US DOLLARS 2010) }\end{array}$ & 5.78 & 33.22 & 78.899 & 653.0 & 464.282 \\
\hline Population (Million) & 5.78 & $2.242 \mathrm{e}+07$ & $2.962 \mathrm{e}+07$ & 435.079 & $1.909 \mathrm{e}+08$ \\
\hline Weighted distance (km) & 5.78 & 3.181 & 1.896 & 56.45 & 8.745 \\
\hline
\end{tabular}

by the Centre d'Études Prospectives et d'Informations Internationales (CEPII) ${ }^{5}$. In order to appreciate the integration process impact on the Africa intra-trade flows, we introduce the variable UM which captures the monetary union effect and binary variables for the African Regional Communities: CEDEAO, SADC, COMESA, ECCAS et UMA.

\subsection{Model Specification Tests}

The first step of using spatial effects is to identify the presence of spatial autocorrelation. The model (9) is estimated using OLS estimator (Table A1) ${ }^{6}$, which mean that the spatial autocorrelation is considered absent. In the spatial econometric literature, there exists three indicators used to detect the presence of the global spatial autocorrelation in quantitative variables: Moran's statistic (Moran, 1948), Geary's statistic (Geary, 1954) and Getis's statistic (Getis \& Ord, 1992). These statistics are used to test the flowing assumptions:

- $H_{0}$ : Absence of spatial autocorrelation in the error term

- $H_{1}$ : The error term presents a spatial dependence

Table 2 presents the result of the spatial autocorrelation tests using the Moran, Geary and Getis statistics. The result indicates that bilateral exports flow, industrial exports and agricultural of African countries present a positive spatial dependence. The different statistics are significant at $1 \%$ and show that the ${ }^{5}$ Centre d'Études Prospectives et d'Informations Internationales. http://www.cepii.fr/ ${ }^{6}$ Appendix (Table A1). 
Table 2. Global spatial dependence detection.

\begin{tabular}{cccc}
\hline Tests & Total exports & Industrial Trade & Agricultural Trade \\
\hline Moran I & $0.193^{\star * *}$ & $0.162^{\star * *}$ & $0.127^{\star * *}$ \\
Geary GC & $0.816^{\star * *}$ & $0.846^{* * *}$ & $0.884^{\star * *}$ \\
Getis-Ords GO & $-0.193^{\star * *}$ & $-0.162^{\star * *}$ & $-0.127^{\star * *}$ \\
Moran $I_{\varepsilon}$ & $47.66^{\star * *}$ & $40 .^{* * *}$ & $31.45^{\star * *}$ \\
\hline
\end{tabular}

Significance threshold ${ }^{\star * *} p<0.01,{ }^{* *} p<0.05,{ }^{*} p<0.1$.

alternative assumption of presence of spatial dependence can't be rejected at $1 \%$. Thus, pass over the spatial autocorrelation leads fallacious regressions and incorrect statistical inference.

Once the spatial autocorrelation has been detected, it is necessary to identify the appropriate way to model the spatial dependence. The Spatial Lagrange Multiplier test and it robust version, developed by Anselin (1988a, 1988c), are performed to identify the suit model. Table 3 exposed Lagrange multiplier and Lagrange multiplier robust tests results. The two tests $\left(L M_{\rho}\right.$ et $\left.L M_{\lambda}\right)$ are significant at $1 \%$ but $L M_{\rho}$ statistic is higher than $L M_{\lambda}$ statistic. It means that the SAR model (7) is the pertinent spatial model to analyze African countries trade determinants on the period 2002-2018. The result confirmed Tientao (2015) who also found that the SAR Tobit model is the appropriate spatial model to analyze trade interdependence in Africa context on cross section data.

\section{Results and Discussions}

Table 4 presents the estimations results using the maximum likelihood estimator for the Spatial Autoregressive gravity model. Our main objective is to identify intra-African trade determinants after taking account the spatial effects. We used three dependent variables: total exports, industrial exports and agricultural exports and the spatial statistics show all of these flows present a positive spatial dependence. In the table, the indirect effect match to the spatial effects. The indirect effect captures the mean effect of the spatial diffusion of the variables of the economies located in the proximity of the partners on their export flows. As predicted by the spatial detection tests, the spatial coefficient $\rho$ is positive and significant at $1 \%$ for all the trade flows among African countries. This result suggests that the OLS estimators are biased and not convergent. Hence, the result confirms the role of spatial dependence in the analysis of international trade. The result shows that exports flow between economy $i$ and its partner $j$ is also affected by the mean of trade flows of partners of their neighborhood. Compared the two types of flows, spatial effect of industrial trade is higher than spatial effect in the agricultural export. Indeed, the development of the industrial sector is generally affected by agglomeration of economics activities.

Table 4 shows that all the coefficient of the traditional variables of gravity model have the expected sign. We introduced two variables of distance: the 
Table 3. Specifications tests.

\begin{tabular}{|c|c|c|c|}
\hline Types de test & Total exports & Industrial Trade & Agricultural Trade \\
\hline$L M_{\rho}$ & $3036^{* * *}$ & $2132^{\star \star *}$ & $1335^{\star * *}$ \\
\hline$L M_{\lambda}$ & $2189^{* * *}$ & $1539^{* * *}$ & $948^{* * *}$ \\
\hline$R L M_{\rho}$ & $1004^{* * *}$ & $863^{* * *}$ & $647^{* * *}$ \\
\hline$R L M_{\lambda}$ & $157^{\star * *}$ & $270^{* * *}$ & $261^{\star * *}$ \\
\hline
\end{tabular}

Significance threshold ${ }^{\star *} p<0.01,{ }^{\star *} p<0.05,{ }^{\star} p<0.1$.

Table 4. SAR model estimations results.

\begin{tabular}{|c|c|c|c|c|c|c|c|c|c|}
\hline & \multicolumn{3}{|c|}{ Total Exports } & \multicolumn{3}{|c|}{ Industrial trade } & \multicolumn{3}{|c|}{ Agricultural trade } \\
\hline & $\begin{array}{l}\text { Total } \\
\text { Effect }\end{array}$ & $\begin{array}{l}\text { Direct } \\
\text { Effect }\end{array}$ & $\begin{array}{c}\text { Indirect } \\
\text { Effect }\end{array}$ & $\begin{array}{l}\text { Total } \\
\text { Effect }\end{array}$ & $\begin{array}{l}\text { Direct } \\
\text { Effect }\end{array}$ & $\begin{array}{c}\text { Indirect } \\
\text { Effect }\end{array}$ & $\begin{array}{l}\text { Total } \\
\text { Effect }\end{array}$ & $\begin{array}{l}\text { Direct } \\
\text { Effect }\end{array}$ & $\begin{array}{c}\text { Indirect } \\
\text { Effect }\end{array}$ \\
\hline Bilateral & $-0.659^{* * *}$ & $-0.375^{\star * *}$ & $-0.284^{\star * *}$ & $-0.842^{* * *}$ & $-0.54^{\star * *}$ & $-0.303^{* * *}$ & 0.037 & 0.03 & 0.007 \\
\hline Distance & -0.0708 & & & -0.08 & & & -0.0933 & & \\
\hline Intern & $-1.44^{\star * *}$ & $-0.819^{\star * *}$ & $-0.621^{\star \star \star}$ & $-1.575^{\star \star \star}$ & $-1.001^{\star \star \star}$ & $-0.566^{\star * *}$ & -0.091 & -0.073 & -0.018 \\
\hline Distance & -0.142 & & & -0.156 & & & -0.202 & & \\
\hline Political Stability & $-0.397^{\star * *}$ & $-0.226^{\star * *}$ & $-0.171^{* * *}$ & $-0.337^{\star * *}$ & $-0.216^{* * *}$ & $-0.121^{* * *}$ & $-0.237^{\star * *}$ & $-0.191^{\star * *}$ & $-0.046^{\star * *}$ \\
\hline destination & -0.056 & & & -0.062 & & & -0.073 & & \\
\hline Control of & $-0.254^{\star * *}$ & $-0.109^{* * *}$ & $-0.108^{\star \star *}$ & $-0.246^{\star *}$ & $-0.158^{\star \star}$ & $-0.089^{\star *}$ & -0.109 & -0.088 & -0.021 \\
\hline destination & -0.113 & & & -0.127 & & & -0.155 & & \\
\hline Rules of Law & $0.661^{\star * *}$ & $0.376^{\star * *}$ & $0.285^{* * *}$ & $0.649^{* * *}$ & $0.416^{\star * *}$ & $0.233^{\star * *}$ & 0.262 & 0.21 & 0.051 \\
\hline destination & -0.13 & & & -0.146 & & & -0.172 & & \\
\hline Common & $2.594^{\star * *}$ & $1.475^{\star * \star}$ & $1.119^{\star * *}$ & $2.428^{* * *}$ & $1.556^{\star * *}$ & $0.872^{\star * *}$ & $2.553^{* * *}$ & $2.053^{* * *}$ & $0.501^{\star * *}$ \\
\hline Border & -0.133 & & & -0.148 & & & -0.155 & & \\
\hline Common & $0.174^{\star *}$ & $0.099^{\star *}$ & $0.075^{\star *}$ & $0.266^{\star * *}$ & $0.170^{\star * *}$ & $0.096^{\star * *}$ & -0.181 & -0.146 & -0.036 \\
\hline official Language & -0.088 & & & -0.098 & & & -0.119 & & \\
\hline Common & 0.115 & 0.065 & 0.05 & -0.059 & -0.038 & -0.021 & $-0.487^{\star * *}$ & $-0.391^{\star * *}$ & $-0.095^{\star * *}$ \\
\hline Colonizer & -0.098 & & & -0.109 & & & -0.128 & & \\
\hline Common & $0.458^{\star * *}$ & $0.261^{\star * *}$ & $0.198^{\star * *}$ & 0.313 & 0.201 & 0.113 & 0.364 & 0.293 & 0.071 \\
\hline Religion & -0.171 & & & -0.205 & & & -0.227 & & \\
\hline Landlocked & $-0.651^{\star * *}$ & $-0.371^{\star * *}$ & $-0.282^{\star \star \star}$ & $-0.612^{\star * \star}$ & $-0.392^{\star * \star}$ & $-0.219^{\star \star *}$ & $-0.245^{\star \star \star}$ & $-0.197^{\star * *}$ & $-0.048^{\star * *}$ \\
\hline destination & -0.077 & & & -0.083 & & & -0.103 & & \\
\hline Common & $0.615^{\star * *}$ & $0.350^{* * *}$ & $0.265^{\star * *}$ & $0.552^{\star * *}$ & $0.354^{\star * *}$ & $0.198^{* * *}$ & $0.972^{\star * *}$ & $0.782^{\star * *}$ & $0.191^{\star * *}$ \\
\hline Currency & -0.128 & & & -0.14 & & & -0.161 & & \\
\hline \multirow{2}{*}{ SADC } & $1.583^{* * *}$ & $0.901^{* * *}$ & $0.683^{* * *}$ & $1.37^{* * *}$ & $0.878^{* * *}$ & $0.492^{* * *}$ & $1.185^{\star * *}$ & $0.952^{* * *}$ & $0.232^{* * *}$ \\
\hline & -0.139 & & & -0.153 & & & -0.167 & & \\
\hline
\end{tabular}




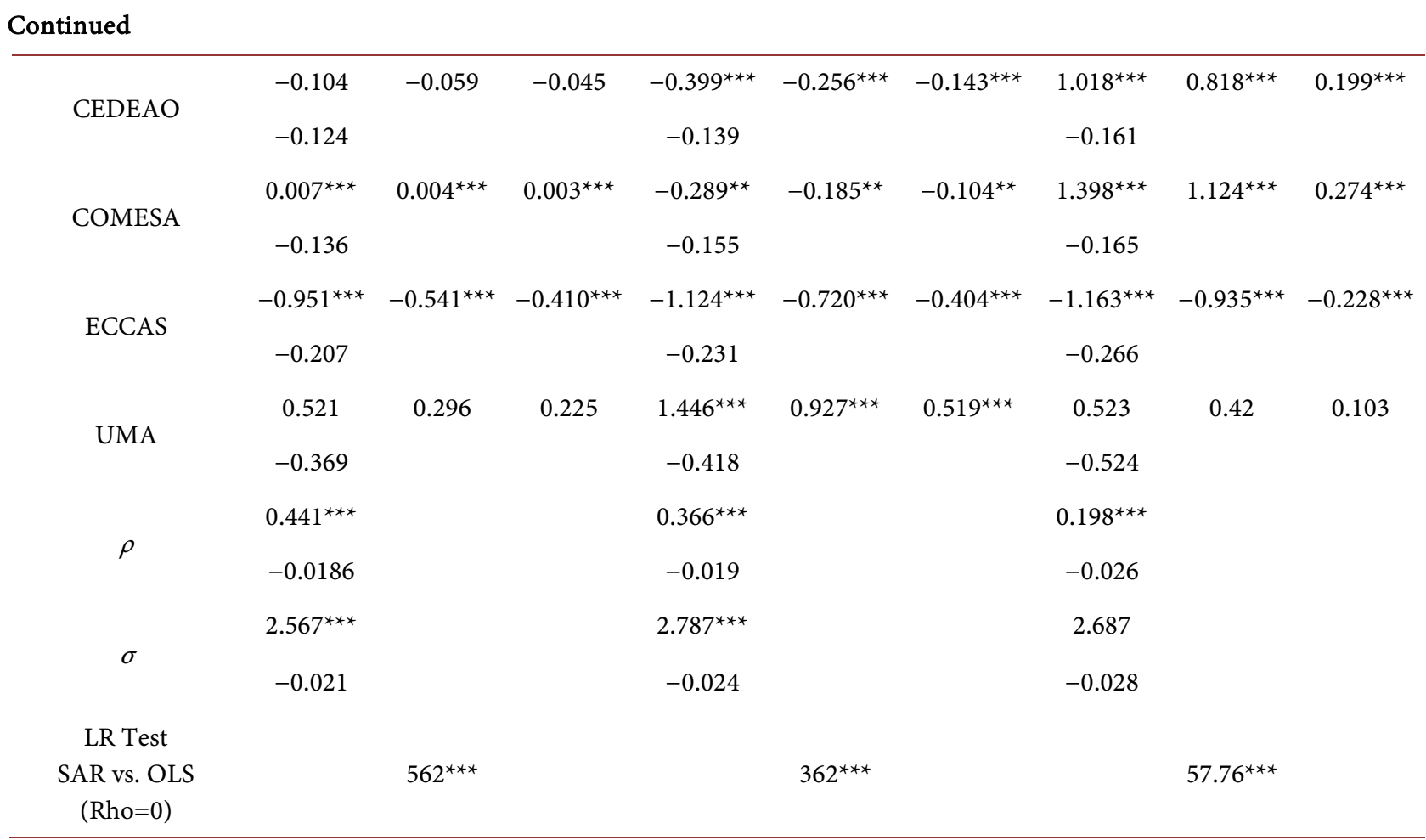

bilateral variable and the intern distance variable because country trade with itself. As expected, the coefficient of bilateral distance sign is negative and significant for total exports and industrial products export. We observed that when the spatial dependence is controlled, distance impact declines. This result confirms the assumption that the distance coefficient is a black box because it does not only reflect the impact of distance. Following Anderson et al. (2016), we define the internal distance which allows a comparison between the international distance and the internal distance. The results show that internal distance has a negative impact on bilateral exports and this effect is greater than the impact of bilateral distance, contrary to the results found in the literature (Head \& Mayer, 2013). This variable, far from capturing only the impact of internal distance, captures all the distortions encountered in the origin country. In developing African countries, infrastructures between countries are often better than internal infrastructures what slackens internal trade. We observed that when the spatial dependence is controlled, the distance impact on agricultural products trade is not significant. This result could be explained by the fact that in the majority of African countries, agricultural flows are more subject to informal trade and take place between border populations. The other geographic factor like distance has an important effect on bilateral trade in African countries context is the landlockedness. When the destination country is landlocked, this negatively affects its imports from others African countries. Indeed, the landlocked is a factor of isolation and tends to increase trade costs. In addition, the landlocked economies due to their low level of development only formulate a low level of demand. 
The negative impact of landlockedness on trade volume is reinforced when trading partners are surrounded by landlocked economies. The landlockedness affects exports of manufactured goods more than those of agricultural products. This result is explained by the weak level of industrialization of these countries and the small size of their markets. It also emerges from Table 4 that geographical proximity, common official language, and common religion are trade promotion factors. We observed that the common official language negatively affects agricultural products trade and this effect is strengthened by the sign of colonial ties.

Our results also show that institutional factors affect trade among African countries. The political instability in the destination country has a negative impact on its imports from African partners. The weakness of political stability in the destination country is negative and significant at the $1 \%$ level across the specification. Political instability in neighboring economies also affects negatively the origin country exports. Indeed, political instability increases checkpoints and decelerate trade between countries. Except the agricultural products trade, the control of corruption in destination country negatively impacts the exports flows of origin country. In fact, the control of corruption in destination country limits its imports from other countries. This result supports the assumption of lubrication of the wheel developed by Méon and Weill (2010) which states that corruption facilitates trade by helping to avoid restrictive procedures. Following Alhassan \& Payaslioglu (2019), it is possible to assert that corruption, by speeding up import procedures, is a lubricant in African countries. The application of the rules of law, on the other hand, positively affects trade among countries. Thus, the institutional quality of the country of destination and that of the economies located in the neighborhood of the partners affects trade between African countries.

The table also exposes integration variables impact on intra-African trade. The table shows that the common currency increases trade among countries and its effect is more important for agricultural trade. Additionally, when neighboring economies use the same currency as partner economies, it tends to facilitate bilateral trade. Our analysis also appreciates African regional economic communities' effects on bilateral trade. The result shows that SADC is the only regional economic community with a positive impact on trade during the analysis period. Thus, SADC has strengthened trade between members with an important impact on industrial trade. When two partners of SADC are surrounded by SADC member economies, it tends to strengthen their trade relations. Over the period 2002-2018, membership of ECOWAS had a negative but insignificant impact on total exports. Indeed, this period while marking the relaunch of the integration process within the area is also marked by periods of economic, social and political instability. When spatial dependance is controlled, it appears that ECOWAS as a regional economic community does not promote industrial trade during the period 2002-2018, its impact on exports of manufactured products is 
negative and significant at the $1 \%$. In contrast, ECOWAS promotes agricultural products exports. Its effect on agricultural products is positive and significant at the $1 \%$. When the two ECOWAS members partners are surrounded by ECOWAS member economies, this tends to increase the volume of agricultural products traded. We note with UNCTAD (2013) which mentioned that considering the ratio of manufacturing activity to GDP, West Africa is the least industrialized African region compared to other areas of the continent. Hence, ECOWAS countries trade is dominated by agricultural products.

Our results show that COMESA has a positive and significant impact at the $1 \%$ threshold on total exports and exports of agricultural products. This effect is more important on agricultural products. On the other hand, it negatively affected industrial products. ECCAS, unlike other RECs, has a negative and significant impact on trade over the period 2002-2018. This area, characterized by conflicts recurrence and leadership problem, does not promote cooperation between members. Our results show that UMA affects only on manufactured products.

\section{Conclusion}

In this analysis, our main objective is to revisit the determinants among Africa countries with the gravity model by giving the emphasis to the spatial aspect. We used the spatial econometric toolkit to model the spatial component presents in the total exports, industrial products and agricultural products of 40 African countries in the period 2002-2018. The results confirm the presence of spatial dependence and show that the Spatial Autoregressive (SAR) model is the good fit used to analyse the determinants of total exports, industrial products and agricultural products exports. This suggests that structural variables exert direct and indirect effects on trade flow. However, the indirect effects tend to be small as compared to the direct effects. This brings to the confirmation of the theory relating to spillovers and locational factors. The results show that distance doesn't affect agricultural products trade, institutional factors of destination country and neighboring countries affect African intra-trade. Also, except SADC area, African intra-trade is largely dominated by agricultural products. Our paper contributes to the literature of determinants of the intra-African trade in one way. First, the best specification of gravity model, this is the first paper that reveals the presence of spatial dependence and takes it into account. To reduce poverty through trade intensification, the regional integration process in Africa must grant an important place to industrialization policies, conflict resolution and strengthening cooperation.

\section{Conflicts of Interest}

The authors declare no conflicts of interest regarding the publication of this paper. 


\section{Authors' Contribution}

Dr. Mariame Bakouan: Conceptualization; Data curation; Formal analysis; Funding acquisition; Investigation; Methodology; Roles/Writing—original draft; Writing.

Pr Idrissa Ouedraogo: Project administration; Supervision; Validation; Visualization.

\section{Funding}

Authors are received funding from the West African Economic and Monetary Union (WAEMU): Resources; Software.

\section{References}

Acemoglu, D., Johnson, S., \& Robinson, J. A. (2001). The Colonial Origins of Comparative Development: An Empirical Investigation. American Economic Review, 91, 1369-1401. https://doi.org/10.1257/aer.91.5.1369

Adam, C., \& Cobham, D. (2007). Modelling Multilateral Trade Resistance in a Gravity Model with Exchange Rate Regimes. Centre for Dynamic Macroeconomic Analysis Conference Papers 2007.

Alhassan, A., \& Payaslioglu, C. (2019). Institutions and Bilateral Trade in Africa: An Application of Poisson's Estimation with High-Dimensional Fixed Effects to Structural Gravity Model. Applied Economics Letters, 27, 1357-1361. https://doi.org/10.1080/13504851.2019.1682112

Anderson, J. E. (1979). A Theoretical Foundation for the Gravity Equation. The American Economic Review, 69, 106-116.

Anderson, J. E., \& Van Wincoop, E. (2003). Gravity with Gravitas: A Solution to the Border Puzzle. American Economic Review, 93, 170-192. https://doi.org/10.1257/000282803321455214

Anderson, J. E., Vesselovsky, M., \& Yotov, Y. V. (2016). Gravity with Scale Effects. Journal of International Economics, 100, 174-193. https://doi.org/10.1016/j.jinteco.2016.03.003

Anselin, L. (1988a). Lagrange Multiplier Test Diagnostics for Spatial Dependence and Spatial Heterogeneity. Geographical Analysis, 20, 1-17. https://doi.org/10.1111/j.1538-4632.1988.tb00159.x

Anselin, L. (1988b). Spatial Econometrics: Methods and Models. Kluwer Academic Publishers.

Anselin, L. (1988c). A Test for Spatial Autocorrelation in Seemingly Unrelated Regressions. Economics Letters, 28, 335-341. https://doi.org/10.1016/0165-1765(88)90009-2

Anselin, L. (2003). Spatial Externalities, Spatial Multipliers, and Spatial Econometrics. International Regional Science Review, 26, 153-166. https://doi.org/10.1177/0160017602250972

Armington, P. S. (1969). A Theory of Demand for Products Distinguished by Place of Production. Staff Papers, 16, 159-178.

Asongu, S. A., Nwachukwu, J. C., \& Orim, S. M. I. (2018). Mobile Phones, Institutional Quality and Entrepreneurship in Sub-Saharan Africa. Technological Forecasting and Social Change, 131, 183-203. https://doi.org/10.1016/j.techfore.2017.08.007

Baltagi, B. H. (2008). Econometric Analysis of Panel Data (4th ed.). John Wiley. 
Baltagi, B. H., et al. (2007). Testing for Serial Correlation, Spatial Autocorrelation and Random Effects Using Panel Data. Journal of Econometrics. https://doi.org/10.1016/j.jeconom.2006.09.001

Barbalet, F., Greenville, J., Crook, W., Gretton, P., \& Breunig, R. (2015). Exploring the Links between Bilateral and Regional Trade Agreements and Merchandise Trade. Asia \& the Pacific Policy Studies, 2, 467-484. https://doi.org/10.1002/app5.101

Baumont, C., Ertur, C., Le Gallo, J. et al. (2000). Geographic Spillover and Growth (a Spatial Econometric Analysis for European Regions). Working Papers HAL-01526987.

Bi, N. N., \& Kong, X. (2022). Analysis of Fijis Regional Trade Using Gravity Model. Open Journal of Business and Management, 10, 17-38.

https://doi.org/10.4236/ojbm.2022.101002

Canh, P. N., Doytch, N., Thanh, S. D., \& Schinckus, C. (2021). Do Institutions and Technologies Matter for Trade Openness? Empirical Evidence from African Countries. The International Trade Journal, 35, 413-438.

Coulibaly, S., \& Fontagné, L. (2006). South-South Trade: Geography Matters. Journal of African Economies, 15, 313-341. https://doi.org/10.1093/jae/eji030

Curry, L. (1972). A Spatial Analysis of Gravity Flows. Regional Studies, 6, 131-147. https://doi.org/10.1080/09595237200185141

De Groot, H. L., Linders, G. J., Rietveld, P., \& Subramanian, U. (2003). The Institutional Determinants of Bilateral Trade Patterns. Tinbergen Institute Working Paper No. 03-044/3. https://doi.org/10.2139/ssrn.417323

Fally, T. (2015). Structural Gravity and Fixed Effects. Journal of International Economics, 97, 76-85. https://doi.org/10.1016/j.jinteco.2015.05.005

Feenstra, R. C. (2004). Advanced International Trade: Theory and Evidence. Princeton University Press.

Gallup, J. L., Sachs, J. D., \& Mellinger, A. D. (1999). Geography and Economic Development. International Regional Science Review, 22, 179-232. https://doi.org/10.1177/016001799761012334

Geary, R. C. (1954). The Contiguity Ratio and Statistical Mapping. The Incorporated Statistician, 5, 115-127, 129-146. https://doi.org/10.2307/2986645

Getis, A., \& Ord, J. K. (1992). The Analysis of Spatial Association by Use of Distance Statistics. Geographical Analysis, 24, 189-206. https://doi.org/10.1111/j.1538-4632.1992.tb00261.x

Hall, S. G., \& Petroulas, P. (2008). Spatial Interdependencies of FDI Locations: A Lessening of the Tyranny of Distance? Department of Economics, University of Leicester, Leicester.

Head, K., \& Mayer, T. (2013). What Separates Us? Sources of Resistance to Globalization. Canadian Journal of Economics/Revue Canadienne d'Économique, 46, 1196-1231. https://doi.org/10.1111/caje.12055

Head, K., \& Mayer, T. (2014). Gravity Equations: Workhorse, Toolkit, and Cookbook. In G. Gopinath, E. Helpman, \& K. Rogoff (Eds.), Handbook of International Economics (Vol. 4, pp. 131-195). Elsevier. https://doi.org/10.1016/B978-0-444-54314-1.00003-3

Kamau, N. L. (2010). The Impact of Regional Integration on Economic Growth: Empirical Evidence from COMESA, EAC and SADC Trade Blocs. American Journal of Social and Management Sciences, 1, 150-163. https://doi.org/10.5251/ajsms.2010.1.2.150.163

Kaminchia, S. M. (2019). The determinants of trade costs in the East African community. Journal of Economic Integration, 34, 38-85. https://doi.org/10.11130/jei.2019.34.1.038 
Kelejian, H. H., Tavlas, G. S., \& Petroulas, P. (2011). In the Neighborhood: The Trade Ects of the Euro in a Spatial Framework. Regional Science and Urban Economics, 42, 314-322. https://doi.org/10.1016/j.regsciurbeco.2011.09.007

Krugman, P. (1991). Geography and Trade. MIT Press.

Le Gallo, J. (2000). Econométrie spatiale (1, autocorrélation spatiale). Laboratoire d'Analyse et de Techniques Économiques (LATEC).

Le Gallo, J. (2002). Disparités géographiques et convergence des régions européennes: Une approche par l'économétrie spatiale. Ph.D. Thesis, Université de Bourgogne.

Lee, M. L., \& Pace, R. K. (2005). Spatial Distribution of Retail Sales. The Journal of Real Estate Finance and Economics, 31, 53-69. https://doi.org/10.1007/s11146-005-0993-5

Leibrecht, M., \& Riedl, A. (2014). Modeling FDI Based on a Spatially Augmented Gravity Model: Evidence for Central and Eastern European Countries. The Journal of International Trade \& Economic Development, 23, 1206-1237. https://doi.org/10.1080/09638199.2013.861006

Levchenko, A. A. (2007). Institutional Quality and International Trade. The Review of Economic Studies, 74, 791-819. https://doi.org/10.1111/j.1467-937X.2007.00435.x

Masson, P. R., \& Pattillo, C. (2004). The Monetary Geography of Africa. Brookings Institution Press.

Méon, P. G., \& Weill, L. (2010). Is Corruption an Efficient Grease? World Development, 38, 244-259. https://doi.org/10.1016/j.worlddev.2009.06.004

Metulini, R. (2013). Spatial Gravity Models for International Trade: A Panel Analysis among OECD Countries. European Regional Science Association.

Moran, P. A. P. (1948). The Interpretation of Statistical Maps. Journal of the Royal Statistical Society: Series B (Methodological), 10, 243-251. https://doi.org/10.1111/j.2517-6161.1948.tb00012.x

Ngepah, N., \& Udeagha, M. C. (2018). African Regional Trade Agreements and IntraAfrican Trade. Journal of Economic Integration, 33, 1176-1199. https://doi.org/10.11130/jei.2018.33.1.1176

Nordås, H. K. (2018). What Drives Trade in Services? Lessons from the Nordics. Applied Economics, 50, 3532-3545. https://doi.org/10.1080/00036846.2018.1430334

Porojan, A. (2001). Trade Flows and Spatial Effects: The Gravity Model Revisited. Open Economies Review, 12, 265-280. https://doi.org/10.1023/A:1011129422190

Prager, J. C., \& Thisse, J. F. (2010). Économie géographique du développement. La Découverte.

Redding, S., \& Venables, A. J. (2004). Economic Geography and International Inequality. Journal of International Economics, 62, 53-82. https://doi.org/10.1016/j.jinteco.2003.07.001

Tapsoba, S. J. (2011). Union monétaire en Afrique de l'Ouest: Quelles réponses à l'hétérogénéité des chocs? CERDI, Etudes et Documents, E 2009.12.

Tientao, A. (2015). Commerce international, innovation et interdépendance: Une approche parl'économétrie spatiale. Ph. D. Thesis, Université de Bourgogne.

Tinbergen, J. (1962). Shaping the World Economy: Suggestions for an International Economic Policy, New York, Twentieth Century Fund.

Tobler, W. R. (1979). Cellular Geography. In Philosophy in Geography, pp. 379-386. Springer. https://doi.org/10.1007/978-94-009-9394-5_18

Tsangarides, C. G., \& Qureshi, M. S. (2008). Monetary Union Membership in West Africa: A Cluster Analysis. World Development, 36, 1261-1279. 
https://doi.org/10.1016/j.worlddev.2007.06.019

UNCTAD (2013). Commerce Intra-Africain: Libérer le dynamisme du secteur privé. Rapport 2013: le développement économique en Afrique. Nations Unies, New York et Genève, 2013.

Viner, J. (1950). The Customs Union Issue. Carnegie Endowment for International Peace.

Von Uexkull, E. (2012). Regional Trade and Employment in ECOWAS. Policy Priorities for International Trade and Jobs (pp. 415-446). OECD. 


\section{Appendix}

Table A1. OLS estimation results.

\begin{tabular}{|c|c|c|c|}
\hline & (1) & (2) & (3) \\
\hline & $\begin{array}{l}\text { Total } \\
\text { exports }\end{array}$ & $\begin{array}{c}\text { Agriculture } \\
\text { Trade }\end{array}$ & $\begin{array}{c}\text { Industrial } \\
\text { Trade }\end{array}$ \\
\hline \multirow{2}{*}{ Bilateral Distance } & $-1.866^{\star * *}$ & $-1.327^{\star * *}$ & $-1.900^{* * *}$ \\
\hline & $(0.0372)$ & $(0.0419)$ & $(0.0436)$ \\
\hline \multirow{2}{*}{ Intern Distance } & $-3.944^{* * *}$ & $-2.611^{\star * *}$ & $-3.840^{* * *}$ \\
\hline & $(0.0605)$ & $(0.0685)$ & $(0.0710)$ \\
\hline \multirow{2}{*}{ Political Stability destination } & $-0.382^{\star *}$ & $-0.528^{\star *}$ & -0.168 \\
\hline & $(0.190)$ & $(0.230)$ & $(0.228)$ \\
\hline \multirow{2}{*}{ Control of corruption destination } & $-1.581^{* * *}$ & -0.448 & $-1.972^{* * *}$ \\
\hline & $(0.302)$ & $(0.339)$ & $(0.357)$ \\
\hline \multirow{2}{*}{ Rules of Law destination } & $2.005^{\star * *}$ & $1.352^{\star * *}$ & $1.943^{* * *}$ \\
\hline & $(0.247)$ & $(0.328)$ & $(0.325)$ \\
\hline \multirow{2}{*}{ Common Border } & $1.302^{* * *}$ & $2.715^{\star * *}$ & $1.695^{\star * *}$ \\
\hline & $(0.0524)$ & $(0.0764)$ & $(0.0637)$ \\
\hline \multirow{2}{*}{ Common official language } & $0.464^{* * *}$ & $0.156^{\star * *}$ & $0.673^{* * *}$ \\
\hline & $(0.0426)$ & $(0.0516)$ & $(0.0533)$ \\
\hline \multirow{2}{*}{ Common colonizer } & $0.537^{\star * *}$ & $0.609^{\star * *}$ & $0.537^{\star * *}$ \\
\hline & $(0.0480)$ & $(0.0590)$ & $(0.0584)$ \\
\hline \multirow{2}{*}{ Common religion } & $0.823^{\star * *}$ & $1.088^{\star * *}$ & $0.404^{* * *}$ \\
\hline & $(0.0807)$ & $(0.0902)$ & $(0.0944)$ \\
\hline \multirow{2}{*}{ Landlocked destination } & $-1.088^{* * *}$ & $-0.539^{\star}$ & $-0.571^{\star}$ \\
\hline & $(0.245)$ & $(0.307)$ & $(0.304)$ \\
\hline \multirow{2}{*}{ Common currency } & $0.265^{\star * *}$ & $0.863^{\star * *}$ & $0.245^{\star * *}$ \\
\hline & $(0.0554)$ & $(0.0766)$ & $(0.0659)$ \\
\hline \multirow{2}{*}{ SADC } & $0.793^{* * *}$ & $0.830^{\star * *}$ & $0.630^{* * *}$ \\
\hline & $(0.0782)$ & $(0.0927)$ & $(0.0897)$ \\
\hline \multirow{2}{*}{ CEDEAO } & -0.0935 & $1.415^{\star * *}$ & $-0.509^{\star * *}$ \\
\hline & $(0.0664)$ & $(0.0792)$ & $(0.0811)$ \\
\hline \multirow{2}{*}{ COMESA } & $1.279^{\star * *}$ & $1.655^{\star \star \star}$ & $0.638^{* * *}$ \\
\hline & $(0.0614)$ & $(0.0982)$ & $(0.0869)$ \\
\hline \multirow{2}{*}{ ECCAS } & $-0.333^{* * *}$ & 0.0111 & $-0.895^{\star * *}$ \\
\hline & $(0.107)$ & $(0.112)$ & $(0.125)$ \\
\hline
\end{tabular}




\section{Continued}

\begin{tabular}{cccc}
\hline UMA & $0.662^{* * *}$ & $-1.790^{* * *}$ & $1.729^{\star * *}$ \\
Exporter fixed effects & $(0.156)$ & $(0.229)$ & $(0.195)$ \\
Importer fixed effects & Yes & Yes & Yes \\
Observations & Yes & Yes & Yes \\
R-squared & 27,200 & 27,200 & 27,200 \\
\hline
\end{tabular}

Robust standard errors in parentheses ${ }^{\star * *} p<0.01,{ }^{\star *} p<0.05,{ }^{\star} p<0$.

\section{Data Sources}

Bilateral trade data are obtained from the World Integrated Service (WITS) https://www.wits.worldbank.org. Macroeconomic variables (real gross domestic product (GDP)) come from the World Bank's World Development Indicator (WDI) of World Bank

http://datatopics.worldbank.org/world-development-indicators//. The data for bilateral distance, common border, common language, colonial ties, and landlocked are from CEPII www.cepii.fr. Institutional quality data are provided by the World Bank's Worldwide Governance Indicators (WGI) https://info.worldbank.org/governance/wgi.

Table A2. Countries list.

\begin{tabular}{|c|c|c|c|}
\hline & Country & Country & Country \\
\hline 1 & Algeria & Ghana & Rwanda \\
\hline 2 & Angola & Guinea & Tome and Principe \\
\hline 3 & Benin & Guinea-Bissau & Senegal \\
\hline 4 & Burkina Faso & Kenya & Sierra Leone \\
\hline 5 & Burundi & Lesotho & South Africa \\
\hline 6 & Botswana & Libya & Tanzania \\
\hline 7 & Cameroon & Madagascar & Togo \\
\hline 8 & Cape Verde & Malawi & Tunisia \\
\hline 9 & Central Africa Republic & Mali & Uganda \\
\hline 10 & Congo & Mauritania & Zambia \\
\hline 11 & Côte d'Ivoire & Morocco & Zimbabwe \\
\hline 12 & Egypt & Mozambique & \\
\hline 13 & Ethiopia & Namibia & \\
\hline 14 & Gabon & Niger & \\
\hline 15 & Gambia & Nigeria & \\
\hline
\end{tabular}

